IRA-International Journal of Education \& Multidisciplinary Studies

ISSN 2455-2526; Vol.06, Issue 01 (2017)

Pg. no. 101-105

Institute of Research Advances

http://research-advances.org/index.php/IJEMS

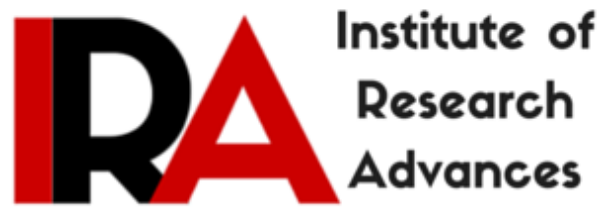

\title{
The Art of Fear Management for the Betterment of Success
}

J. John Sunil Manoah

Academic Advisor, Department of English,

Vethathiri Maharishi High School, Tiruttani, India.

Type of Review: Peer Reviewed.

DOI: http://dx.doi.org/10.21013/jems.v6.n1.p7

\section{How to cite this paper:}

Manoah, J. (2017). The Art of Fear Management for the Betterment of Success. IRA International Journal of Education and Multidisciplinary Studies (ISSN 2455-2526), 6(1), 101-105. doi:http://dx.doi.org/10.21013/jems.v6.n1.p7

(C) Institute of Research Advances

(cc) EY-NC

This work is licensed under a Creative Commons Attribution-Non Commercial 4.0 International License subject to proper citation to the publication source of the work.

Disclaimer: The scholarly papers as reviewed and published by the Institute of Research Advances (IRA) are the views and opinions of their respective authors and are not the views or opinions of the IRA. The IRA disclaims of any harm or loss caused due to the published content to any party. 


\begin{abstract}
Fear is common in humans as well as in animals, it stays somewhere in the $5^{\text {th }}$ sense of mind which is been stimulated by hormones and cells of the brain, hence brain is the vital tool that generates the fear. Literary meaning for fear is stated as an alert by our brain about the occurrence of danger and predicament. Fear is a regular property of the people those who have desire for living, no age factor or maturity has got to do with it, it applies even to a just born child and to the people of old age.Fear is most common among the theist than the atheist, since faith is source to trigger the fear. The people those who don't believe in the external force are less in numbers as a victim of fear.It has got a major role to play in one's success, since the impact of fear will block one's success and stops them to move forward. In this article I write about how to manage the fear within ourselves which I firmly believe will essentially lead us to unstoppable success.
\end{abstract}

Keywords: Fear, Phobia, Mind, Success

\title{
Introduction
}

Before I begin my statement I begin with a famous quote about fear which was said by a legendary football player David Beckham, "he says fear has got two abbreviations.

1. F.E.A.R = "Forget Everything And Run"

2. F.E.A.R = "Face Everything And Rise"

The choice is ours", hence it is proved fear is a kind of feel that was generated within us. It is important to find from where the fear does originates and what are the available sources for the fear to get into us? On answering to these questions we can fetch most two common sources which are eyes and ears for the fear to get inside us, if someone is visually gifted, they can store the visually seen scenes into their minds, the images, portrays, scenes that we see through our eyes will stay in our mind, incase if the visuals have made an impact on us, likewise the sound and the audio whatever we hear or listen which has made an impact on us will stay in our mind, since mind is the only place where the fear is originated as it stores all the scenes and the audios which had made an impact on us. In this article I write about how to manage the fear that originates from our mind which rules and sometimes ruins our success. In regards to this, we go on to discuss more about whether fear is a boon or a curse.

\section{Fear versus Phobia}

The definition that given for phobia in the dictionary is "a fear for specific kind of object, activity or a situation to which one believes will lead to predicament" and for fear it was mentioned as "a distressing emotion or a feel aroused by predicting danger to which one believes that it will lead to complications". Thou both are slightly related in meaning the features and the combinations are different, since phobia is aroused on a specific kind of situations and scenarios but fear can arise at any time depending on the mood of the mind. It doesn't matter with what a person is possessed with either fear or phobia; both are liable for the preventing success, since both fear and phobia never allows anyone to think out of the box and to go beyond. It is like a conductor that blocks one's success. One has to find some sort of source or to eradicate these things out their life, in case if they let to stay on in their life, it will certainly ruin their all future endeavors. 
Table 2.1 Difference between phobia and fear

\begin{tabular}{|c|c|c|}
\hline S.No & Phobia & Fear \\
\hline 1 & It is generated in the conscious mind & It is generated in the sub-conscious mind \\
\hline 2 & It is a curable disease & It is a controllable feel \\
\hline 3 & It has a cause and a reason & It is due to predicting danger \\
\hline 4 & Bad experience is an essential cause & Bad experience is not mandatory \\
\hline 5 & $\begin{array}{l}\text { Impacts the nervous system and cerebral } \\
\text { system directly }\end{array}$ & $\begin{array}{l}\text { Impacts the cerebral system directly and the } \\
\text { nervous system indirectly }\end{array}$ \\
\hline 6 & It comes in the category of disorders & It comes in the category of Issues. \\
\hline 7 & $\begin{array}{l}\text { It requires medication with meditation to } \\
\text { overcome }\end{array}$ & It requires exercise with meditation to overcome \\
\hline
\end{tabular}

\section{Process that induces Fear}

Fear the inborn feel or emotion has got some common features which compiles in all living beings who has got five senses and above, the cells and tissues in the human brain will alert the cerebral system about the danger that present around and presses the nerves which results in pumping the flow of blood with extra pressure. To any humans when things are in normal conditions, the human brain will have an effect on the mind in giving a caution about the fear which will result in the above said process, a change will occur in both physiology and in the anatomy of the body the moment the fear generates, which will eventually prevent the person on going forward. This fear was also triggered by the threat that was guessed by the brain, once it was triggered then the hormones will spontaneously flow a serum called adrenocorticotropic, which will slow down the blood flow and increases the heart rate. The extreme of fear can take one even to the point of death by causing damage to the cells in human brain

\section{Lessons Learnt from Personal Experiences}

In this article I mention about my personal experience that I once had over fear. It happened at the age of 16, being a lover of thrill and adventure, I love preferring to watch lot of horror and thriller movies, the incident that happened on one fine day in my life still hangs, in my memories, on watching horror movie alone for second show, which was quite a good movie to rate in horror category, made me to feel lot of Goosebumps and mind click seven while on my way back home by twelve O'clock at midnight, after food took my bed for sleep, when I got into deep sleep there it all started. A complete guide of disturbance around my night with nightmares, initially it started with a black dog chasing after me, followed by a witch chase and finally a corpse chase. All these things are after me in my dream in order to harm me, which resulted in waking me up from my deep sleep. On getting waking up I realized it was just a dream till before it was very real to me, since it was such a dreadful experience puts me in complete sweat. Having no idea of what to do I told my mom about the worst nightmare that troubled me, being an orthodox Christian she had suggested me to keep the Holy bible on the righter side of my pillow and continue to sleep, as she suggested, somewhere in my half sleep I managed to get the bible and kept at the right side of my pillow and resumed my sleep. The moment it was done I started to feel the good sleep in fact with sweet dreams no more nightmares, quite happy indeed and thankful to the bible for giving me the good sleep, since the belief was on the word of God which was written inside the bible had given me the good sleep. The next morning I woke up by thanking God for giving me a pleasant sleep, and then noticed the book that was kept on my righter side of my pillow is not a bible it's a dictionary. I was quite surprised to see the power of the dictionary and wondered so much. I checked with my family member whether anyone had replaced the bible with dictionary and the answer was 'no'. I was amused and 
puzzled for many long years about the power the dictionary has got, since it took some long years for me to understand that there is nothing in the book it's all in my mind. Then I understood that fear is a feel that is generated within us internally, hence human mind has got all the powers to generate and to destroy everything that happens internally.

\section{Impact of Fear on Success Rate}

Success falls on every individual, thou it is not as per one's expectation it still comes to people up to their level of capabilities. No one can claim that they've never tasted the sweetness of success; at some level everyone must have tasted it. The rate of success may vary from individual to individual but at least some rate would be there, over which the entire humanity is running behind. Nowadays it has become survival more than success, some individual aim for only success and they keep working forward no matter whatever comes in the middle, but most of the individuals will satisfy with the level of survival itself. Fear plays a vital role in success rate, more than in success I can say in success rate. Assume if someone deserves $100 \%$ of success in any of his endeavors and falls as a victim of fear then definitely success rate will be reduced on, even it might take them to get the credit of less than $10 \%$. Fear will never allow anyone to progress on, we have practically witnessed from the life of cricketing legend Sachin Tendulkar as he gets more out on 90's before hitting the century score, which was due to fear, in case if he had overcome the fear that he gets while moving onto the score of 90's he would have hit the 100 centuries a long time back. Therefore it's the success rate is always slowed down by the fear.

\section{Measures to Manage Fear}

1. The first step to do in order to manage the fear is to understand that fear is something generated and triggered by our own mind

2. The second step is to believe in our potential and mental capabilities, like if mind has got the power to generate a fear and the same mind will have the power to destroy it.

3. The next element is to understand the nature, as it is nature to be born and nature to die, everyone at some point of time is going to face the death, the love and passion for living has to stay on with courage to face the death at any time.

4. The voice of humans has got tremendous powers, since it can instruct our mind by saying that "we can't live with fear in order to live free", the more we say this slogan to ourselves the possibilities are there to dry the fear out of the mind.

5. To the theist many objects are available in the market to wear and use on, which will also do wonder in eradicating the fear, which are not certainly believed by the atheist, as they believe in the system of self-confidence and self-motivation to avoid the fear.

6. Fear has got some worst consequences, the moment the fear is generated the mind has to send a caution about the worst consequences of fear, which will definitely help them within to bring down the fear.

\section{Conclusion}

Fear is a distressing outcome of emotion which can be controlled for sure, it's all within the powers of human mind, the only thing that the individual has to do is to understand the capabilities of the mind power which is the only tool to destroy and eradicate the fear, at some point of time that everyone has to find a measure to overcome and eradicate this feel out of their life, incase if anyone lets it to stay in, then it will definitely ruin their success rate. Believing in oneself and self-motivation are the sources to remove the fear out of the mind. 


\section{References}

[1] Manoah, Dr. J John. "The Art Of Tuning Mind \& Shifting Gear For The Purpose Of Living Enhancement." International Education and Research Journal [Online], 2.4 (2016): n. pag. Web. 5 Nov. 2016

[2] The Holy Bible, New International Version. Grand Rapids: Zondervan House, 1984. Print.

[3]https://www.psychologytoday.com/blog/the-mindful-self-express/201212/ten-skills-manage-fearand-anxiety-in-unsafe-world 